Integritas 4.1 (Fall 2014), pp. 1-15.

doi: 10.6017/integritas.v4i1p1

\title{
A School of Nonviolence?
}

\section{William Werpehowski}

\begin{abstract}
While Roman Catholic moral teachings affirm in principle that a national government has a right to defend its people from grave and unjust threat through armed conflict, the Church has moved more and more in a direction that sturdily suspects violence of any sort, that asserts a fundamental moral presumption against war, and that aspires to nonviolence of spirit in everyday

life. I consider the Catholic university in the light of this movement.
\end{abstract}

This essay is an attempt to spark thinking and conversation on the following question: what would it mean for a Catholic university to be, essentially or constitutively, a school of nonviolence?

I begin with a statement, relying on developments in Catholic moral and social thought, which indicates why the question is reasonable for folks specifically interested in the mission and purpose of Catholic higher education. Part II proposes that "nonviolence" and "peaceableness" characterize and mediate both the "enlargement of mind" and the "enlargement of heart" duly sought in Catholic college education and life. In Part III, I follow Forster's dictum, "Only connect," with reflections about the sorts of questions a nonviolent Catholic school and its culture may prompt and press.

In academic writing, it is often at this point that authors issue their cautions and disclaimers. Thus we read such sentences as "My intentions are modest," "My aims are quite limited," and "I will not be able to consider in detail the important issue of this, or that." Were I to name and list all the qualifications that apply here, we would never arrive at Part I (call this a second order caution or disclaimer!). For example, and as a mere sample, I am not at all sure how exactly to define "violence" and "nonviolence," as I risk impossible breadth at one pole and impossible narrowness at the other. My

William Werpehowski is the Robert L. McDevitt, K.S.G., K.C.H.S. and Catherine H. McDevitt, L.C.H.S. Chair in Catholic Theology at Georgetown University. A former president of the Society of Christian Ethics, Dr. Werpehowski was director of Villanova's Center for Peace and Justice Education from 1999-2010. He is the author of Karl Barth and Christian Ethics, American Protestant Ethics and the Legacy of $\mathrm{H}$. Richard Niebuhr, and co-editor, with Gilbert Meilaender, of The Oxford Handbook of Theological Ethics. 
discussion will not arrive at careful analyses of the several topics that arguably are at the practical center of my leading question, including the scary prevalence of sexual assaults against women on campus and policies regarding ROTC programs. To some of my readers, the sources I employ will appear not only eclectic but downright eccentric. Et cetera. Nevertheless, my essay is what it is and not another thing, i.e., an invitation or interrogation or maybe a provocation to set our thought for a moment and for a start on nonviolence as being at the core of the vision and practice of Catholic higher education.

\section{Recent Catholic reflection on nonviolence}

In his I983 Warsaw Lectures, the late John Howard Yoder gave lengthy attention to "varieties of Catholic peace theology" present and even on the way to prevailing since the middle of the last century. He saw these as amounting to a kind of nonviolent "movement,"

in the broad sense it has come to have, namely, a discernable commonality of numerous initiatives not coordinated from one center or dictated by one doctrine but which can be seen to be moving along one path. ${ }^{\mathrm{I}}$

In this section I present some significant features of such a movement in the same broad sense. My account overlaps with Yoder's in some ways but not in others, and it also considers the period following ig83.

Within Catholic social teaching, a growing commitment to nonviolence in situations of international conflict emerged in critical conversation with its traditional and longaccepted "just war theory." Since the end of World War II, papal statements from Pius XII forward expressed concern over the damage and harm wrought by war as well as over convenient and quick suppositions that war is and can be in reality an instrument of justice. ${ }^{2}$ A signature moment in the conversation was the U.S. bishops' I983 proposal that there is a "presumption against war" that holds alongside the "presumption against injustice" which would warrant in certain cases violent resistance in defense of the innocent. ${ }^{3}$ The bishops write directly of the "paradox" that nonviolent opposition to injustice best reflects the call of Jesus to love and justice, but that violent response may yet be in our world a tragic moral necessity.4 They also endorse without equivocation a pacifist option for individual Christians that "is not passive about injustice and the defense of the rights of others" but "rather affirms and exemplifies what it means to resist injustice through non-violent methods." Just war teaching and nonviolence

1 John Howard Yoder, Nonviolence: A Brief History (Waco, TX: Baylor University Press, 2010), 109.

2 For a concise statement, see Kenneth R. Himes, O.F.M., "Peacebuilding and Catholic Social Teaching," in Peacebuilding: Catholic Theology, Ethics, and Praxis, ed. Robert ). Schreiter et al. (Maryknoll, NY: Orbis Books, 2010), 279-83.

3 See William Werpehowski, "A Tale of Two Presumptions: The Development of Roman Catholic Just War Theory," in Linda Hogan, ed., Applied Ethics in a World Church (Maryknoll, NY: Orbis Books, 2008), 119-25.

4 National Conference of Catholic Bishops (NCCB), The Challenge of Peace (Washington, DC: United States Catholic Conference, 1983), 78-82. 
appear together as "distinct but interdependent methods of evaluating warfare"; "each contributes to the full moral vision we need in pursuit of a human peace." 5

A decade later in The Harvest of Justice is Sown in Peace, the bishops made the moral preference for nonviolence in international relations clearer and stronger. Drew Christiansen argues that, indeed, it emerges as a full-blown "state ethic" demanded prior to and thus conditionally authenticating legitimate recourse to armed conflict. ${ }^{6}$ Harvest also offered a rich if condensed account of "peaceable virtues" that, "amid the violence of contemporary culture and in response to the growing contempt for human life," may affect and complete the whole of Christian existence and community.

We need to nurture among ourselves faith and hope to strengthen our spirits by placing our trust in God, rather than in ourselves; courage and compassion that move us to action; humility and kindness so that we can put the needs and interests of others ahead of our own; patience and perseverance to endure the long struggle for justice; and civility and charity so that we can treat others with respect and love. ${ }^{7}$

During the pontificate of John Paul II, serious questions were raised-many by the Pope himself-about how just war theory functions ideologically as a rationalization for war, and how it is that war is always, whatever "good" it may do or promise to do, a

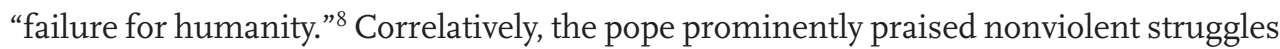
in defense of human rights, as in the case of the Solidarity movement in his native Poland. ${ }^{9}$ More recently, Benedict XVI's comments on Jesus' injunction to love your enemies are stirring.

This page of the Gospel is rightly considered the "Magna Carta" of Christian nonviolence; it does not consist in surrendering to evil...but in responding to evil with good, and thus breaking the chain of injustice. It is thus understood that nonviolence for Christians is not mere tactical behavior but a person's way of being, the attitude of one who is convinced of God's love and power, who is not afraid to confront evil with the weapons of love and truth alone. Loving the enemy is the nucleus of the "Christian revolution," a revolution not based on strategies of economic, political, or media power. ${ }^{\circ}$

5 NCCB, The Challenge of Peace, 116-121.

6 Drew Christiansen, S.J., "Reading the Signs of the Times: Just Nonviolence and Peacemaking" (unpublished).

7 National Conference of Catholic Bishops, The Harvest of Justice is Sown in Peace (1993), www.usccb. org/beliefs-and-teachings/what-we-believe/catholic-social-teaching/the-harvest-of-justice-is-sownin-peace.cfm.

8 Address of His Holiness John Paul II to the Diplomatic Corps (January 13, 2003), www.vatican.va/holy father/john_paul_ii/speeches/2003/january/documents/hf_jp-ii_spe_20030113_diplomatic-corps_ en.html.

9 John Paul II, Centesimus Annus 22-25, online at www.vatican.va.

10 Benedict XVI, "Angelus," February 18, 2007, www.vatican.va/holy_father/benedict_xvi/angelus/2007/ documents/hf_ben-xvi_ang_20070218_en.html. 
No less remarkable are these words by Benedict about Jesus Christ himself.

He came with only the strength of love, totally without violence, even to the point of going to the Cross. This is what shows us the true face of God, that violence never comes from God, never helps bring anything good, but is a destructive means and not the path to escape difficulties. He is thus a strong voice against every type of violence. He strongly invites all sides to renounce violence, even if they feel they are right....This is Jesus' true message: seek peace with the means of peace and leave violence aside. ${ }^{\text {II }}$

\section{It is fair to say that the moral tradition that Pope Francis inherits and may continue includes a robust call to nonviolence.}

It is fair to say that the moral tradition that Pope Francis inherits and may continue includes, even if tensively, a robust call to nonviolence, a fierce opposition to the inhumanity of war, and the sober and lamentable recognition that the use of (proportionate and discriminating) armed force to protect the innocent remains, however tragic, a moral option as a reasonable last resort.

The absolute pacifism of Dorothy Day and Daniel Berrigan, and the (seemingly) "just war pacifism" of Thomas Merton, have contributed to this tradition while also standing over against it. All three highlight that nonviolent Christian discipleship does not acquiesce in the face of injustice but rather opposes and resists it. Along the way Day regularly called attention to the connections between "class war" and its associated inhumanity toward the poor, "imperialist war," and "preparations for war." ${ }^{\text {I2 }}$ Berrigan followed her lead with an "ethic of resurrection" sharply skeptical about the state and its regular tendency to demand of its citizens an idolatrous loyalty. ${ }^{\mathrm{I} 3}$ His vision effectively directs attention to the pernicious practices, rituals, and symbols that he finds constitutive of a systemic political reality that nourishes itself on its pretension to be the lord of life and death. What Berrigan writes about Day announces a project he shares with her.

Peace, she teaches, implies the making of peace. It is never done with. It implies resistance against the "filthy rotten system" (her words) that makes of us drudges and cowards and war tax-paying chattels, that adroitly adjusts our will and conscience, like the sinister clockwork of a time bomb-adjusts us to a world of injustice and cruelty and death. ${ }^{\mathrm{I}}$

11 "Only the Strength of Love: Interview with Benedict XVI," L'Osservatore Romano, April 23, 2011. 
Thomas Merton shared the concern about war, war making, and mystification. In addition, he addressed the "Christian roots of nonviolence" with remarkable precision and insight. Christian nonviolent action for justice and peace is distinct from not only moral passivity but also the "moral aggression" "designed...to bring out the evil we hope to find in the adversary, and thus to justify ourselves in our own eyes and in the eyes of 'decent people." It is a struggle "for the truth, common to [oneself] and to the adversary, the right which is objective and universal." The nonviolent disciple is "fighting for everybody," ${ }^{5}$ and for her or him the virtues of hope and humility are indivisible:

the meekness and humility which Christ extolled in the Sermon on the Mount are inseparable from an eschatological Christian hope which is completely open to the presence of God in the world and therefore in the presence of the brother who is always seen, no matter who he may be, in the perspective of the Kingdom. ${ }^{\mathrm{I}}$

In that stance, nonviolent, self-giving love is extended with the hope that it may be redemptive, i.e., that it will contribute to liberating persons and communities from imprisoning distortions of human identity such as apathy, moral blindness, contempt, hatred, and other forms of prideful or slothful exclusion. ${ }^{\mathrm{I}}$

John Dear follows Day, Berrigan, and Merton in his own categorical commitment to a nonviolent life, understood positively as a life of "active peacemaking and persistent reconciliation." ${ }^{18}$ Such a life demands comprehending the vast extent of the violence of our world, which

occurs on many levels, from the violence within us, to interpersonal and societal violence, to the global structural violence of war, nuclear weapons, environmental destruction, hunger, sexism, racism, homelessness, abortion, torture, the death penalty and...rampant poverty.... ${ }^{\text {I9 }}$

Dear's inventory can lead one-can lead me-to lose his (my) bearings. As intimated above, I am wary of definitions of violence and nonviolence that are so sweeping that they finally obscure rather than illuminate our understanding of evils and goods, and of vices and virtues, in the ways they specifically and particularly present themselves. But I am equally suspicious of accounts of violence that are so restrictive that they leave us with nothing but, say, the problem of war, or killing generally, to talk about.

For the purposes of this essay I will err in the direction of greater breadth. I have

15 Thomas Merton, Passion for Peace (New York: Crossroad Publishing Company, 1995), 89-90.

16 Merton, 104.

17 I discuss the figures and ideas of the last two paragraphs more fully in "Self-Giving, Nonviolence, Peacemaking: An Approach to Catholic Moral Life and Christ's Passion," Engaging the Passion, ed. Oliver Larry Yarbrough (Fortress Press, forthcoming).

18 John Dear, The God of Peace: Toward a Theology of Nonviolence (Maryknoll, NY: Orbis Books, 1994), 10. More recently see Dear's The Nonviolent Life (Long Beach, CA: Pace e Bene Press, 2013); and Eli Sasaran McCarthy, Becoming Nonviolent Peacemakers: A Virtue Ethic for Catholic Social Teaching and U.S. Policy (Eugene, OR: Pickwick Publications, 2012).

19 Dear, The God of Peace, 5-6. 
three explanatory resources in mind. First, I follow John Paul II's observation that an increasingly critical eye toward specific forms of violence, i.e., warfare and the death penalty, represents "signs of hope" regarding respect for human life generally and, indeed, the victory of life over death is accomplished in Jesus Christ. ${ }^{2 \circ}$ The sturdy suspicion of violence in this or that expression thus elicits broader suspicions with it and renewed commitment to an "ethic of resurrection" steeped in nonviolence. Second, I presuppose the legitimacy and explanatory power of distinctions between "deadly," "structural," and "cultural" violence; these all concern the wrongful violation of human persons in their fundamental needs as free and embodied agents and participants in social life. ${ }^{2 \mathrm{I}}$ The distinctions help to manage and articulate our grasp of how and why our social life goes ugly and bad at the same time as they might suggest their (nonviolent) correction. Finally, I will nonetheless stipulate that the reality of war has a focal priority; it brings into helpful focus the "narrow" or "narrower" problem of "just" versus "unjust" killing (deadly violence), but also is a practice with consequences and conditions that point to significant sorts of structural and cultural violence involving, for example, the grave and disproportionate suffering that war and preparation for war brings and sustains among poor populations, the demonizing of our "enemies" (at home and abroad), and the degradation of democratic politics and culture.

If a Catholic university is a place where, as Rev. Theodore Hesbergh famously quipped, "the Church does its thinking," and if the Church has increasingly decried war and other forms of violence while commending nonviolence in word, spirit, and practice, then the Catholic university should be a means to peace by thinking increasingly about violence and nonviolence. It may be a "school of nonviolence" in just this sense. Yes? Yes, but then again, no.

\section{Nonviolence and Catholic universities}

Nonviolence and violence are not just big topics to study and think about in a Catholic university. Nonviolence and peaceableness are constitutive of practices of humanistic inquiry themselves, i.e., of the practices and attendant virtues that make Catholic universities what they are and ought to be, morally speaking. Because of this deeper unity and because of the themes presented in Part I, we can affirm what the first sentence of this paragraph says, without the "not just"; but ideally the study will work hand in hand with the nurturance of a particular sort of character among students and teachers alike. Or so I shall argue.

In a I997 contribution to Commonweal, my friend and colleague Stephen Pope presents a practical, dialectical, and still timely approach to the question of a Catholic

20 John Paul II, Evangelium Vitae (1995), 27, online at www.vatican.va.

21 For an excellent account of these distinctions as they have emerged in peace studies and related areas, see Jason A. Springs, "Violence that Works on the Soul': Structural and Cultural Violence in Religion and Peacebuilding," in The Oxford Handbook of Religion and Peacebuilding, ed. Atalia Omer, Scott Appleby, and David Little (Oxford: Oxford University Press, forthcoming). 
school's purpose and vocation. ${ }^{22}$ "Catholic universities," he writes,

cannot simply be places where well-to-do students receive a good education in order to assume their place in the next generation of corporate and professional elites. How does education of the relatively affluent...relate to concern for those on the other end of the social and economic spectrum?

He answers the question by showing how the insights of Jon Sobrino and John Henry Newman critically complement one another.

Sobrino believes that "the educational dimension of a university is not a sufficient justification" for the Christian university. The problem is one of "horizon; of whether, consciously or unconsciously, the educational values to be promoted are determined from the few rather than from the many, or even against the many." ${ }^{23}$ Instead, since it is "invited and required to incarnate itself in one reality or another, placing its social weight on behalf of one or the other," ${ }^{24}$ the Christian university should be "a place for the poor." It is necessary

that it see the world from the point of view of the poor and that this world have entered into the university's mind and heart....The option for the poor makes a Christian university possible and moreover grants it a credibility that enhances its influence in society. ${ }^{25}$

\section{The preferential option for the poor, so much at the core of Pope Francis's social vision today, "justifies" Catholic higher education.}

Thus the preferential option for the poor, so much at the core of Pope Francis's social vision today, ${ }^{26}$ "justifies" Catholic higher education. In Pope's analysis, "compassion must have a central place in the life of the Catholic university; the preferential option entails solidarity-identifying with the poor, being converted by them, and participating in movements for their empowerment." Otherwise it will "reinforce present structures of injustice, oppression, and exclusion." ${ }^{27}$

Pope sees Newman's The Idea of a University as presenting "the strongest challenge

22 Stephen Pope, "A Vocation for Catholic Higher Education?" Commonweal (March 28, 1997), at www. bc.edu/content/dam/files/offices/mission/pdf1/cu19.pdf.

23 Jon Sobrino, S.J., "The University's Christian Inspiration," in Jon Sobrino, Companions of Jesus: The Jesuit Martyrs of El Salvador (Maryknoll, NY: Orbis Books, 1990), 156.

24 Sobrino, 152.

25 Sobrino, 162.

26 For Francis the "clear and direct" message of the Gospel is to show "brotherly love" and offer "humble and generous service" in "justice and mercy" toward the poor, the lost, "those whom society discards." Evangelii Gaudium, 194-195, online at www.vatican.va.

27 Pope, "A Vocation for Catholic Higher Education?" 
to Sobrino's position." The point is that "liberal education" is a good in itself, and that that good should not be justified by or confused with its instrumental utility or its moral motivation. The "enlargement of mind" to which knowledge and learning are directed is an integrative intellectual habit; it is

the power of viewing many things at once as one whole, of referring them severally to their true place in the universal system, of understanding their respective values, and determining their mutual dependence....It makes every thing in some sort lead to everything else. ${ }^{28}$

Such intellect, neither obsessed with one object nor entirely unmoored,

cannot be partial, cannot be exclusive, cannot be impetuous, cannot be at a loss, cannot but be patient, collected, and majestically calm, because it discerns the end in every beginning, the origin in every end, the law in every interruption, the limit in each delay; because it ever knows where it stands, and how its path lies from one point to another. ${ }^{29}$

Stepping away from the hyperbole, we can comprehend with Pope how this enlargement is a "powerful antidote to bigotry, apathy, and social myopia."

Thus Newman corrects Sobrino's exclusive attention to compassion and the cause of the poor in liberal education; but Sobrino is right in terms of the "core ideals" of the Catholic university. Its credibility lies in "whether its graduates are generally concerned about 'taking the crucified people down from their crosses.'” Pope concludes that "institutions of higher education that are at once true universities and genuinely Catholic must be characterized in terms of both an 'enlargement of heart' and an 'enlargement of mind."”

Now it may be possible to link the respective ideals of Newman and Sobrino more securely by endorsing the latter's claim that the "view from below" is authentically projected toward truth and universality, and then developing the claim to show how it incorporates the good of liberal education's "enlargement of mind." $3 \circ$ I will try to connect them differently by I) imagining the practices of study and learning as nonviolent attention, and 2) conceiving of the school that gives learning a home as a "form of peace."

Consider C.S. Lewis's observations about what "good reading” involves.

Good reading...though it is not essentially an affectional or moral or intellectual activity, has something in common with all three. In love we escape from our self into one other. In the moral sphere, every act of justice or charity involves putting ourselves in the other person's place and thus transcending our own

28 John Henry Newman, The Idea of a University (Notre Dame, IN: University of Notre Dame Press, 1982), 103-104.

29 Newman, 104.

30 Sobrino writes that from the perspective of the poor "one can observe reality better and more thoroughly, and act more effectively to improve reality"; moreover, the option for the poor "does not mean to focus on a part of the whole in order to ignore the rest, but rather to reach out to the whole from the part." "The University's Christian Inspiration," 162. 
competitive particularity. In coming to understand anything we are rejecting the facts as they are for us in favor of the facts as they are....In love, in virtue, in the pursuit of knowledge, and in the reception of the arts, we are doing this. Obviously this process can be described either as an enlargement or as a temporary annihilation of self. But that is an old paradox, "he that loseth his life shall save it." ${ }^{31}$

Lewis is referring to varieties of self-forgetfulness or release from self-preoccupation in the service of getting the point, or getting nearer the truth of things, or testing a hypothesis, or reaching an insight. This self-emptying or kenosis is essential to academic work. It includes both a passion for the truth and objectivity about it, humility and selfcriticism so not to cut what is the case to the shape of our desires, and the patience to wait for the light to shine and illumine us.

This way of "paying attention," as Simone Weil has argued famously, is not a matter of gritting your teeth and seeking a willful mastery over the "subject matter." It is rather a humble waiting, "suspending our thought, leaving it detached, empty, and ready to be penetrated by the object." ${ }^{2}$ We can understand "attention" as nonviolent in several ways. It opposes the idea that the object of our learning is finally a thing subject to our will, only to be forced into this or that straitjacket of our personal or collective interests, ideologies, or needs. It is rooted in desire, a kind of love from which would spring joy, which permits and prompts a readiness or inclination to clear-sightedness. With our studies and in anticipation of our moral relations, attention "lets difference emerge without searching for comforting commonalities, dwells upon the other, and lets otherness be." It teaches us "how real things can be looked at and loved without being seized and used, without being appropriated in the greedy expansion of the self." 33 Thus Weil points out that the love of our suffering neighbor (and the love of God!) is "made of the same substance," for it

simply means being able to say to him: "What are you going through?" It is a recognition that the sufferer exists, not only as a unit in a collection or a specimen from the social category labeled "unfortunate," but as a man, exactly like us, who was one day stamped with a special mark by affliction. For this reason it is enough, but it is indispensable, to know how to look at him in a certain way. This way of looking is first of all attentive. The soul empties itself of all its own contents in order to receive into itself the being it is looking at, just as he is, in all his truth. 34

With reference to the reality of war-or more precisely here, its unreality-attentive learning may expose and turn away from "empty words" with "capital letters," the

31 C.S. Lewis, An Experiment in Criticism (Cambridge: Cambridge University Press, 1969), 138.

32 Simone Weil, "Reflections on the Right Use of School Studies with a View to the Love of God," in Waiting for God (New York: Harper Collins, 1973), 62. Sara Ruddick, Maternal Thinking: Towards a Politics of Peace (Boston: Beacon Press, 1989), 122, 121. Weil, "Reflections on the Right Use of School Studies," 64-65. 
"myths and monsters" that often dominate cultural and political discourse so to rationalize war, offer no finally definable objective for it, obscure the facts on the ground of mutilated bodies and minds, and perpetuate its "ultimate" sacrifices only in the name of vindicating the sacrifices that precede them. Hence "the sacrifices already incurred are a perpetual argument for new ones." 35 But absolutes and abstractions- "freedom," "democracy," "our way of life"-lose their deadly power when they pass through the fire of "the very elements of intelligence: the ideas of limit, measure, degree, proportion, relation, comparison, contingency, interdependence, interrelation of means and ends." 36 When in play, all of these elements presuppose a self-emptying act that decenters lofty slogans and ideologies and the individual and collective egos that wield them.

I find it clarifying to think about how it is that, as Stanley Hauerwas has put it, the university most basically "is not a means to peace but is a form of peace." Along with their practices of inquiry and learning,

universities are dedicated to continuing the conversation across centuries of the hard-won wisdom of people who often sharply disagree. The university is committed to exposing those disagreements, believing that by doing so our lives will be lived more honestly and richly. The university, therefore, stands as an activity that thrives on disagreements while believing that such disagreements can never be resolved by violence. 37

\section{The university as a school of nonviolence mediates the enlargement of heart and the enlargement of mind.}

On these grounds, the university as a school of nonviolence mediates the enlargement of heart and the enlargement of mind depicted in this section. The skills of attention and seeking truth in the midst of disagreement and conflict should promote the kind of neighbor love and compassion for the suffering poor endorsed by Sobrino and articulated by Weil. The process of learning, moreover, inherently includes components that nurture an integrative habit of mind; for attention includes

holding in our minds, within reach of this ["empty"] thought, but on a lower level and not in contact with it, the diverse knowledge we have acquired which we are forced to make use of. Our thought should be in relation to all particular and already formulated thoughts, as a man on a mountain who, as he looks

35 Simone Weil, "The Power of Words," in The Simone Weil Reader, ed. George A. Panichas (Mt. Kisco, NY: Moyer Bell Limited, 1977), 269-71.

36 Weil, "The Power of Words," 271.

37 Stanley Hauerwas, "Taking Time for Peace: The Ethical Significance of the Trivial," in Christian Existence Today (Durham, NC: Labyrinth Press, 1988), 261. 
forward, sees also below him, without actually looking, a great many forests and plains. ${ }^{38}$

Attention directed at this body of thought, I want to add, promises a grasp of the whole and the connections within it, a grasp, to repair to Newman, neither obsessed with one thing nor completely loosed.

\section{Questions about a school of nonviolence}

Here is a partial set of questions that a school of nonviolence will pose about itself and its local environs, and to itself and to the persons and communities who populate itstudents, teachers, officers, and so forth. Of course, the questions also interrogate the larger "environs," the worlds of culture, work, and political life. I will continue, I am sure, to dissatisfy my readers by asking questions only, and schematically at that. But from such dissatisfaction might spring better, more concrete questions, and maybe also even some answers.

First, is the school publicly self-conscious about the practices and associated virtues that I (incompletely) described in Part II? Are there shared understandings and programs and processes in place, regarding academic mission and spiritual ministry, that enable and empower the school to communicate, commend, discuss, and gain deeper comprehension of those practices and virtues? It is possible to arrange for this, I think, with clarity, conviction, and connection to prevailing traditions and charisms particular to Catholic colleges. At least, I am hopeful that it is possible given my (admittedly brief) experience at Georgetown University, where I find a more or less lively awareness and appreciation among students, faculty, and administrators of such Ignatian identityconstituting goals as contemplation in action, cura personalis, community in diversity, and service for others. These do not seem to me matters of mere branding, although these goals may and do conflict with and can be overwhelmed by others.

Second, is the school vigilant not only in promoting these practices and virtues within and outside the classroom but in preserving them from corruption? The virtues of attention and peaceableness themselves require among practitioners attendant excellences of honesty, justice, and courage - the first to identify accomplishment, the second to honor it, and the last to take risks in pursuing it. ${ }^{39}$ What is more, and following Merton, we would like to have learning environments which find the mean between the "moral aggression" that makes learning and conversation depend on "showing up" those who disagree as vicious or benighted and a "moral passivity" that fails to stand up for the truth as one discerns it over against resistance. The truth is "for everybody." A test of the authentic search for it is a readiness to see and indeed embrace the truth in those who oppose you; and therefore here, too, humility and hope are indivisible. How do teaching styles, student dynamics, approaches to grading, and the framing of critical debate advance or hinder these virtues along with those of self-forgetful attention? And

38 Weil, "Reflections on the Right Use of School Studies," 62.

39 See Alasdair Maclntyre, After Virtue (Notre Dame, IN: University of Notre Dame Press, 1981), 178-180. 
then there is this: at both the Catholic schools I have served, some and sometimes many faculty members question the way a heavy university emphasis on research and publication subordinates or undermines excellence in teaching. My question about this question is what are the specific purposes of the heavy research emphasis? What are its costs? If the emphasis is expressed in a rank or eye-winking reduction of teaching to "putting in the time" rather than perfecting a nonviolent craft, and if the cost is that student minds and hearts and wholeness are neglected, then we have hypocrisy and violence afoot. Georgetown counts itself a "student centered research university." That description gets the ideal about right, I would say, for a Catholic school of its specific kind. But how do we do that, and how well are we doing at it?

Third, a question closely related to the last is, how are the nonviolent and peaceable practices, goods, and virtues of a nonviolent school affected by the institutions that can and do both foster and endanger such practices? In this connection I am relying on Alasdair MacIntyre's well-known and still useful distinction:

Chess, physics and medicine are practices; chess clubs, laboratories, universities, and hospitals are institutions. Institutions are characteristically and necessarily involved with...external goods. They are involved in acquiring money and other material goods; they are structured in terms of power and status, and they distribute money, power and status as rewards. Nor could they do otherwise if they are to sustain not only themselves, but also the practices of which they are the bearers. For no practices can survive for any length of time unsustained by institutions....[I]nstitutions and practices characteristically form a single causal order in which the ideas and the creativity of the practice are always vulnerable to the acquisitiveness of the institution, in which the cooperative care for the common goods of the practice is always vulnerable to the competitiveness of the institution. In this context the essential function of the virtues is clear. Without them, without justice, courage and truthfulness, practices could not resist the corrupting power of institutions..$^{\circ}$

Acknowledging along the way that the word "university" is now doing double duty, i.e., meaning both an "institution" and a reality constituted by moral practices, I'll ask more questions, even if simply and crudely, in the spirit of the original. Where does a Catholic school and its advancement office seek and get its money and why? How does it distribute rewards and why? Will its admissions and aid policies perpetuate class privileges that effectively hurt the poor and vulnerable or not? In either case, how and why? Where is funding for research sought, what is the research for, to whom is it beholden-and why?

Fourth, how does a Catholic school work against violence and the inhumanity of war in its relation to and stances toward the life of culture and the world of work? The school whose practices help to prevent war is unceasingly thinking, and thinking counter to the dimensions of culture whose practices do not. Speaking from her own powerful 
feminist (if also, alas, classist) vision in I938, Virginia Woolf calls us out today:

Let us never cease from thinking-what is this 'civilization' in which we find ourselves? What are these ceremonies and why should we take part in them? What are these professions and why should we make money out of them? ${ }^{41}$

The upshot of such thinking can and may and must be education for and achievement of an emancipatory act, a "freedom from unreal loyalties," by which Woolf means

that you must rid yourself of pride of nationality in the first place; also of religious pride, college pride, school pride, family pride, sex pride and those unreal loyalties that spring from them. Directly the seducers come with their seductions to bribe you into captivity, tear up the parchments; refuse to fill the forms. $4^{2}$

We add here the "pride of possessions" that moves consumerist culture and springs from its creation of artificial needs. Regarding its connection with war, moreover, we recall the words of the Quaker abolitionist John Woolman: "May we look upon our treasures and the furniture of our houses and the garments in which we array ourselves and try whether the seeds of war have any nourishment in these our possessions or not." 43 I presume generally to understand these "prides" in an Augustinian sense, i.e., they are the pathetic mimicry of the divine in a futile search for an impossible security that permits one to dominate and exclude. And so, C.S. Lewis writes, "of course, power is what Pride really enjoys: there is nothing makes a man feel so superior to others as being able to move them about like toy soldiers. Pride is competitive by its very nature: that is why it goes on and on." 44 But to make persons into things-in our minds and hearts and dreams and deeds-is of the essence of violent force. ${ }^{45}$

Competition, with its both deadening and death-dealing potential, can also infect work and the professions. The evidence of (men's) professional life in the late I930s led Woolf to question "its spiritual, its moral, its intellectual value," leading her to the opinion

41 Virginia Woolf, Three Guineas (New York: Harcourt Brace Jovanovich, 1938), 63. The passage concludes: "Where in short is it leading us, the procession of the sons of educated men?" We are challenged to locate today what and whose processions we may be urged to join - patriarchal, racist, classist - that we should think not only twice but unceasingly about, and with a view to critique and transformation.

42 Woolf, 80. I am suggesting that a school of nonviolence may, if you will, promote and teach this kind of freedom. Woolf rather observes how such freedom has been a great teacher to women roundly excluded from the "rights and privileges" of "educated men" bound to these loyalties and their objects. The observation, needless to say, is important for coming to understand the potentially liberating character of a "preferential option for the poor," a "view from below."

43 John Woolman, "A Plea for the Poor," in The Journal and Major Essays of John Woolman, ed. Phillips P. Moulton (New York: Oxford University Press, 1971), 255.

44 C.S. Lewis, Mere Christianity, Revised and Enlarged Edition (HarperSanFrancisco, 2009), 123.

45 Simone Weil defines "force" as "that $x$ that turns anybody who is subjected to it into a thing" in "The Iliad or the Poem of Force," in Revisions, ed. Stanley Hauerwas and Alasdair Maclntyre (Notre Dame, IN: University of Notre Dame Press, 1983), 222-248. 
that if people are highly successful in their professions they lose their senses. Sight goes. They have no time to look at pictures. Sound goes. They have no time to listen to music. Speech goes. They have no time for conversation. They lose their sense of proportion-the relations between one thing and another. Humanity goes. Money making becomes so important that they must work by night as well as by day. Health goes. And so competitive do they become that they will not share their work with others though they have more than they can do themselves. What then becomes of a human being who has lost sight, sound, and a sense of proportion? Only a cripple in a cave. $4^{6}$

Today this account has to be qualified and revised, especially in light of the distinctive but no less burdensome experiences of women in the workplace and professions, and the struggles of an exploited, invisible workforce of persons denied rights of social and political membership. Still, we can say that a Catholic school will be alert to name, explore, and challenge the violence to human beings that our contemporary workplace embodies and communicates.

Fifth, what are the tasks a Catholic school must undertake in its relation to political life, and in particular the political acts of war and preparations for it? Beyond unmasking the "myths and monsters" already mentioned, the tasks include reflection on the character and extent to which our political life and governments are themselves governed by a "military-industrial" (or "military-industrial-congressional" or "military-industrialcongressional-media" or "military-industrial-congressional-media-educational") complex that always tips our common life toward armed conflict. Analyses of international relations should not be dominated by "security studies" and "realist" stances, but involve vigorous critical consideration of alternative perspectives sensitive to the preservation of moral values in politics, nonviolent conflict resolution, and peacebuilding, Catholic or otherwise. Across the curriculum, the various sorts and sources and expressions of violence in our common life-lethal, structural, cultural-call for examination, and so do the sources and models of peace and nonviolence as we find them not only in work together in college, but also in history, literature, the sciences, religious life, families and friendships. Needless to say, Roman Catholic colleges also should clearly and critically teach how it is that just war theory may be, while allowing the justifiability of war as a last resort, a form of practical reasoning that aims also and especially to prevent it.

\section{Conclusion}

In closing, I want to underscore two themes already mentioned above. First, my argument gives a certain primacy to the practices of teaching and learning that are embodied daily in the Catholic college classroom. Second, the Catholic school of nonviolence that I envision, given the tradition and movement I discuss in Part I, is not a school of "absolute pacifism."

Further reflection on my topic should go forward in conversation with approaches to 
Catholic higher education that emphasize, for example, the virtue of hospitality, religious pluralism, friendship, and contemplation. ${ }^{47}$ What is distinctive and should be stressed here, however, is that the sort of character that fits and should be promoted within a Catholic school of nonviolence is, on the one hand, a character haunted by Tolstoy's pronouncement that "acceptance of the need to oppose evil with violence is nothing other than the justification people give to their habitual and favorite vices: vengeance, avarice, envy, ambition, pride, cowardice and spite." ${ }^{48}$ On the other hand, if the Catholic university is in its educational practices and policies a form of peace, its members may be blessed and empowered to turn away from those vices and learn humbly how it is that, even when violence may indeed be necessary to oppose evil, "there is no way to peace; peace is the way." 49

47 Aurelie A. Hagstrom, "The Role of Charism and Hospitality in the Academy," Integritas 1/1 (Spring 2013); Chester Gillis, "Welcoming the Religiously Other to a Catholic University," Integritas 1/3 (Spring 2013); Marian K. Díaz, "Friendship and Contemplation: An Exploration of Two Forces Propelling the Transcendent Hope and Power of the Liberal Arts," Integritas 2/2 (Fall 2013).

48 Leo Tolstoy, A Confession and Other Religious Writings (London: Penguin Books, 1987), 216.

49 A.J. Muste, at http://en.wikiquote.org/wiki/A._J._Muste. 
